\title{
ANTIOXIDANT ACTIVITIES OF CURCUMIN TO MDA BLOOD SERUM CONCENTRATION AND LEAD LEVELS IN LIVER OF MICE
}

\author{
Sugiharto $^{1 a^{*}}$, Win Darmanto ${ }^{1 b}$, Sri Puji Astuti ${ }^{1 c}$, Alfiah Hayati ${ }^{1 d}$, Yani Martha ${ }^{1 e}$, Putri \\ Olivia $^{\text {If }}$, Kevita Putri ${ }^{1 g}$ \\ ${ }^{1}$ Biology Department, Faculty of Science and Technology, Universitas Airlangga, Surabaya-60115, INDONESIA. \\ Email: totoksbioua@gmail.com $;$ a windarmanto@fst.unair.ac.id ${ }^{\mathrm{b}}$; $\quad$ sri-p-a-w@fst.unair.ac.id ; \\ alfiahayati64@yahoo.com ${ }^{\mathrm{d}}$; Yani.martha@yahoo.co.id ; Putri.oliviar@gmail.com ${ }^{\mathrm{f}}$; kevita.putri@gmail.com ${ }^{\mathrm{g}}$ \\ *Corresponding author: totoksbioua@gmail.com ; sugiharto@fst.unair.ac.id \\ Submitted: 22 $2^{\text {nd }}$ December $2018 \quad$ Accepted: $9^{\text {th }}$ July $2019 \quad$ Published: $30^{\text {th }}$ November 2019
}

DOI: https://doi.org/10.22452/mjs.sp2019no3.3

\begin{abstract}
Human and animals can accidentally be exposed to heavy metals from the environment such as lead $(\mathrm{Pb})$. Lead may induce oxidative stress. It can increase the production of free radicals, and induces several responses in physiological and biochemical functions of the body. Curcumin, a major component of turmeric, is commonly used as a spice and in traditional medicine. The objective of this research was to evaluate the antioxidant activities of curcumin in mice that were exposed to lead. Research was conducted using twenty five male mice, which were grouped into five treatments: P1 (control), P2 (Pb 75 mg/kg BW), P3 (Pb 150 mg/kg BW), $\mathrm{P} 4(\mathrm{~Pb} 75 \mathrm{mg} / \mathrm{kg} \mathrm{BW}+$ curcumin $20 \mathrm{ppm}), \mathrm{P} 5$ (Pb $150 \mathrm{mg} / \mathrm{kg} \mathrm{BW}+$ curcumin $20 \mathrm{ppm})$. The results showed that antioxidant activities of curcumin was very strong with an IC-50 was 9.0 ppm. $\mathrm{Pb}$ exposure increased MDA level $(17.143-17.891 \mu \mathrm{M})$ and $\mathrm{Pb}$ level in the liver $(0.070$ $0.071 \mathrm{mg} / \mathrm{kg} \mathrm{BW})$. Administration of curcumin $20 \mathrm{ppm}$ have the potential to reduced MDA level (14.592-15.714 $\mu \mathrm{M})$ and reduce Pb levels $(0.035-0.038 \mathrm{mg} / \mathrm{kg} \mathrm{BW})$.
\end{abstract}

Keywords: Antioxidant, Curcumin, Lead, Liver, MDA

\section{INTRODUCTION}

One of the heavy metals accumulation that has the potential to poison is lead $(\mathrm{Pb})$. The main mechanism of lead toxicity is via oxidative stress induction. It induces several responses to physiological and biochemical functions in the body. The indicators of the occurrence of heavy metal poisoning in tissues are blood components and liver function. Lead toxicity depends on the dose and time length of exposure (Flora et al., 2012; Fuente et al., 2002; Xu et al., 2008).

Sharma and Singh (2014) showed that the administration of lead-acetate in mice at
$150 \mathrm{mg} / \mathrm{kg} \mathrm{BW}$ for 40 days, significantly reduced the endogenous antioxidant enzyme, superoxide dismutase (SOD) and catalase (CAT) and increased lipid peroxidation in kidney organs, and inactivated glutathione (GSH) and antioxidant enzymes such as SOD and CAT (Flora et al., 2012). According to Al-Fartosy et al., (2017), exposure of petroleum pollutants and heavy metals increases malondialdehyde (MDA) levels in gasoline station workers through induction of oxidative stress reactive oxygen species (ROS) are produced continuously. The endogenous antioxidant enzymes help to neutralize the impact of ROS. Hayati et al., 
(2017) observed that heavy metals in the gonads and the liver of Barbodes sp resulted in cell damage and cell necrosis. Lead exposure at doses of $50 \mathrm{mg} / \mathrm{Kg}$ and 100 $\mathrm{mg} / \mathrm{kg} \mathrm{BW}$ causes oxidative stress and alter protein expression associated with apoptosis in liver of mice (Xu et al., 2008).

Oxidative stress can be alleviated with exogenous antioxidants. Antioxidant stops the oxidation process by neutralizing free radicals that formed during oxidation and convert free radicals into stable forms. The function of antioxidants is to eliminate ROS generated in the body. Indonesia is a mega biodiversity country, with plants possesing medicinal properties such as curcumin, a main constituent of tumeric rhizomes. Sugiharto et al., (2013) and Sugiharto et al., (2016) reported that curcumin has been shown to exhibit strong antioxidant activities with low toxicity, and as a tyrosinase inhibitor to reduce hyperpigmentation in cell B16-F1, because it have phenolic compounds that are responsible for its antioxidant activities (Priyadarsini et al., 2003). The aim of this research was to investigate the antioxidant activities of curcumin in mice exposed to lead. The antioxidant activities of curcumin were evaluated by 2,2-diphenyl-1-picrylhydrazyl (DPPH) method, and its effects studied from concentration of blood serum MDA and lead level in the liver of mice.

\section{MATERIAL AND METHODS}

\subsection{Animals and Materials}

The research used male mice (Mus musculus, strains Balb/C), aged 8-10 weeks from the Faculty of Pharmacy, Airlangga University, Surabaya. Curcumin (SigmaAldrich C1386), DPPH (Sigma-Aldrich D9132), MDA kit Bioassay TBARS Assay
Kit (DTBA-100), lead acetate was obtained from local chemical stores. Atomic Absorption Spectroscopy (AAS - Perkin Elmer Analyst 300), Eppendorf micropipette, centrifuge (Eppendorf 5424R), microplate reader (Multiskan Go - Thermo scientific), was carried out in Molecular Genetic Laboratory, Faculty of Sciences and Technology, Airlangga University, Surabaya.

The use of animal subjects for the research have been approved by Ethics Committee of the Faculty of Veterinary Medicine, Airlangga University (certificate no. 2.KE.100.06.2018).

\subsection{Determination of Curcumin Antioxidant Activity}

The antioxidant activity of curcumin was determined by DPPH methods (Lee et al., 2009). Radical scavenging activities were tested using $100 \mu \mathrm{l}$ curcumin at various concentrations placed into 96 well plates with ethanol solution as a control. Five microliter $2.5 \mathrm{mM}$ DPPH was added followed by 30 minutes incubation in the dark. Antioxidant activity of vitamin $\mathrm{C}$ was compared to curcumin. The percentage of scavenging activity measured at $\lambda=517 \mathrm{~nm}$ in a microplate reader was calculated by equation (1):

$\%$ Scavenging Activity $=[($ Abs. control - Abs. sample) / Abs. control] $\times 100 \%$ (1)

\subsection{Lead Exposure and Curcumin Treatment}

Twenty five mice were acclimated for seven days and then randomly gathered into five treatment groups normalized to per $\mathrm{kg}$ body weight (BW):

P1: $0.4 \mathrm{~mL}$ of distilled water (control) 
P2: $0.4 \mathrm{~mL}$ of lead solution $75 \mathrm{mg} / \mathrm{kg}$ BW

P3: $0.4 \mathrm{~mL}$ of lead solution $150 \mathrm{mg} / \mathrm{kg}$ BW

P4: $0.4 \mathrm{~mL}$ of lead solution $75 \mathrm{mg} / \mathrm{kg}$ $\mathrm{BW}+0.4 \mathrm{~mL}$ curcumin $20 \mathrm{ppm}$

P5: $0.4 \mathrm{~mL}$ of lead solution $150 \mathrm{mg} / \mathrm{kg}$ $\mathrm{BW}+0.4 \mathrm{~mL}$ curcumin $20 \mathrm{ppm}$

The lead treatment was given every morning (08:00 to 09:00 hours), while curcumin was administered in the afternoon (15:00 to 16:00 hours). The treatments were administered orally for 30 days using injection syringe with a round tip (a cannula).

On the last day of treatment, the mice were sacrificed, and blood samples were taken using intra-cardiac technique. The blood samples were centrifuged at 3,000 rpm for 10 minutes at $10{ }^{\circ} \mathrm{C}$ by centrifuge to harvest the serum. Liver tissues were also taken for determining lead level by AAS (Ugya and Imam, 2017) and histopathological analysis by Hematoxylin Eosin (HE) staining (Sugiharto et al., 2018).

\subsection{MDA Assay}

The assay was performed using Bioassay TBARS Assay Kit (DTBA-100) according to the kit manufacturer instruction (BioAssay System). Briefly, $100 \mu \mathrm{L}$ of serum sample and $200 \mu \mathrm{L}$ of $10 \%$ TCA were mixed in a microtube, and incubated on ice for five minutes. The mixture was centrifuged at $14,000 \mathrm{rpm}$ for 5 minutes. Then, $200 \mu \mathrm{L}$ of the supernatant was transferred into a fresh tube. Standard MDA, serum sample and $200 \mu \mathrm{L}$ TBA reagent were mixed through vortexing, then incubated at $100{ }^{\circ} \mathrm{C}$ for $60 \mathrm{~min}$. After the tubes were cooled to room temperature, they were recentrifuged after vortexing. Aliqouts of 100 $\mu \mathrm{L}$ mixture were loaded into 96 well plates, and absorbance $(A b s)$ measured at $\lambda=535$ $\mathrm{nm}$ on a microplate reader. MDA level was calculated using equation (2):

MDA level $(\mu \mathrm{M})=\left\{\left(A b \mathrm{~s}_{\text {sample }}-\right.\right.$ $\left.A b s_{\text {blank }}\right) /$ Slope standard MDA $\} \times$ dilution factor (2)

\subsection{Determination of Lead Concentration in Liver}

Lead level analysis was performed with slight modification from Ugya and Imam (2017), by drying the liver in $180{ }^{\circ} \mathrm{C}$ oven. Sample was mashed and weighed approximately two grams. Approximately $20 \mathrm{ml}$ of $\mathrm{HNO}_{3}$ was added and heated at 300 ${ }^{\circ} \mathrm{C}$ until brown-colored fumes disappeared. Perchlorate nitrate was added to the mixture in a ratio of $1: 1(\mathrm{v} / \mathrm{v})$, followed by heating to obtain a clear solution. The mixture was chilled and then transferred into $100 \mathrm{ml}$ flask for filtration using Whatman no. 41 filter paper. The filtrate was used for Atomic Absorption Spectroscopy (AAS) measurement.

\subsection{Statistical Analysis}

The statistical analyses were performed using SPSS 16.0. ANOVA and Duncan's Multiple Range Test (DMRT) at 5 $\%$ significance level were applied. Data for antioxidant activity of curcumin was fitted to a logarithmic model to determine $\mathrm{IC}_{50}$.

\section{RESULTS AND DISCUSSION}

\subsection{Antioxidant Activity of Curcumin}

Antioxidants stop the oxidation process by neutralizing free radicals and convert them into stable forms. The strength 
of an antioxidant activity is inferred from its $\mathrm{IC}_{50}$ value viz. the smaller its value, more powerful its activity. The widely used method to measure antioxidant activity is DPPH assay, which is easy, fast and sensitive. DPPH is a stable free radical that can react with antioxidant compounds through $\mathrm{H}$ atoms donation. The reaction changes the color of DPPH solution and its absorbance can be determined at $517 \mathrm{~nm}$ (Molyneux, 2004).
In this research, the $\mathrm{IC}_{50}$ of curcumin was determined at $9.0 \mathrm{ppm}$ relative to vitamin $\mathrm{C}$ (3.0 ppm) (Figure 1). A compound is a very potent antioxidant if its $\mathrm{IC}_{50}<50$ $\mathrm{ppm}$. It is clear that the antioxidant activities of curcumin and vitamin $\mathrm{C}$ are similarly strong. Curcumin acts as an antioxidant because it contains phenolic compounds, and the associated and donatable $\mathrm{H}$ atoms are responsible for the antioxidant activities (Molyneux, 2004; Nimse and Pal, 2015; Priyadarsini et al., 2003).

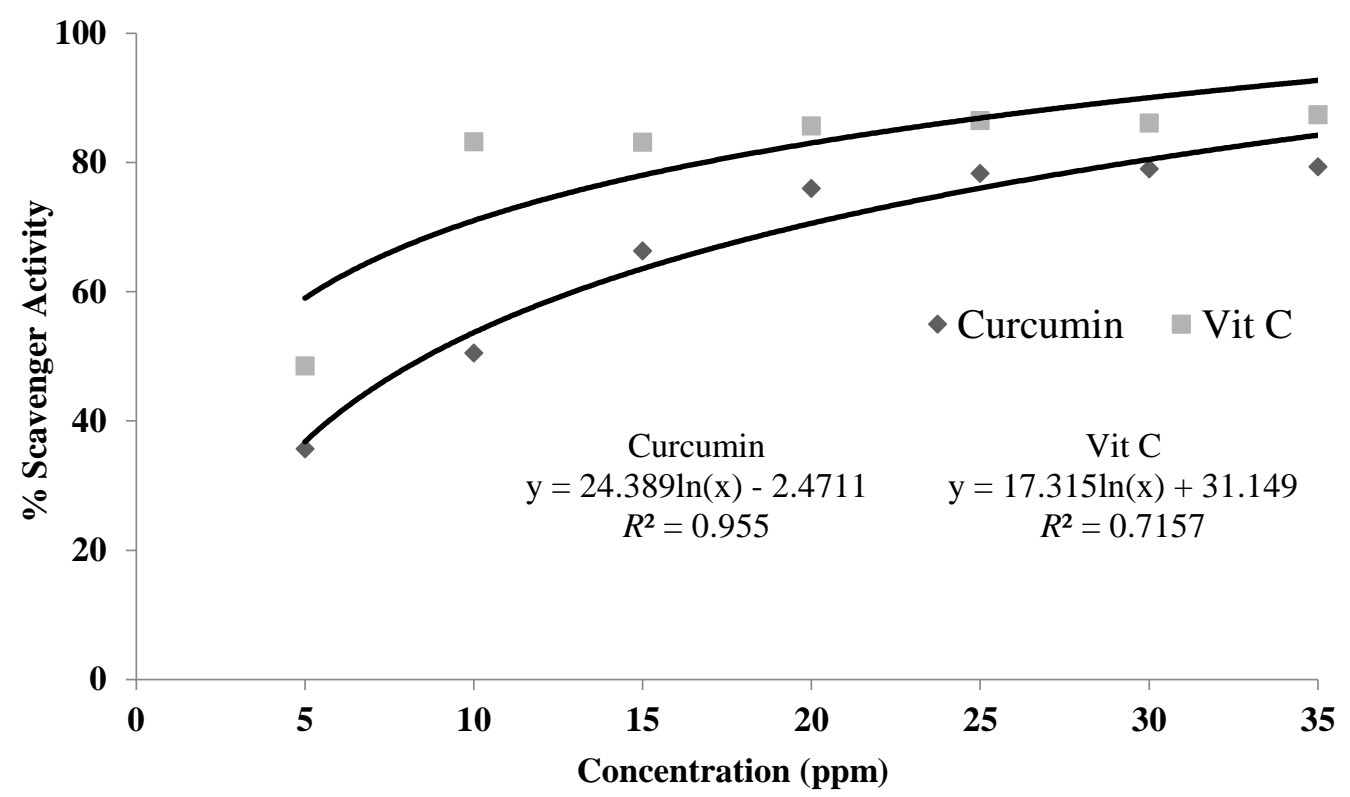

Figure 1. The logarithmic trendline antioxidant activity of curcumin and vitamin $\mathrm{C}$

\subsection{Assay of MDA Concentration}

Lead exposure induces several physiological and biochemical responses in the cells. According to Flora et al. (2012), the main mechanism of lead toxicity is via oxidative stress. It leads to the increase in free radicals production and reduced endogenous antioxidants.

Lead exposure can increase concentration of mice blood serum MDA, and curcumin administration helped to reduce the MDA levels (Table 1). On the contrary, ANOVA test had shown an insignificant results $(p=0.067)$. Al-Fartosy et al., (2017), reported that exposure of petroleum pollutants and heavy metals increased MDA levels in gasoline station workers. Lead acetate significantly

increased the levels of ROS and MDA in 
mice (Xu et al., 2008). Acute and chronic lead exposure increased renal lipid hydroperoxides, and decreased SOD and CAT as antioxidant enzymes (Sharma and Singh, 2014). Lead exposure also decreased both of SOD enzyme in the blood serum and liver cell (Sugiharto et al., 2018). The degenerative effect in liver cells is due to the production of ROS following lead-induced oxidative stress that may eventually result in cell death.

The reduction in the presence of endogenous antioxidant enzymes, which is supposedly to neutralize the impact of ROS, necessitates the intake of exogenous antioxidants. The administration of curcumin can help in reducing blood serum MDA concentration since it is a powerful antioxidant (Sugiharto et al., 2018).

Table 1. Concentration of MDA in blood serum $(\mu \mathrm{M})$

\begin{tabular}{|c|c|c|c|c|c|c|c|}
\hline \multirow[t]{2}{*}{ Treatments } & \multicolumn{6}{|c|}{ Replication } & \multirow{2}{*}{$\begin{array}{c}\text { Conc. of MDA } \pm \text { SD } \\
(\mu M)\end{array}$} \\
\hline & 1 & 2 & 3 & 4 & 5 & 6 & \\
\hline Control & 10.408 & 11.837 & 14.490 & 16.735 & 15.510 & 13.265 & $13.707 \pm 2.350$ \\
\hline $\mathrm{Pb} 75$ & 13.878 & 12.857 & 16.327 & 17.347 & 23.265 & 23.673 & $17.891 \pm 4.615$ \\
\hline $\mathrm{Pb} 150$ & 15.510 & 15.918 & 17.551 & 17.347 & 18.776 & 17.755 & $17.143 \pm 1.218$ \\
\hline $\mathrm{Pb} 75+\mathrm{Cur}$ & 16.327 & 16.531 & 14.898 & 13.878 & 14.694 & 17.959 & $15.714 \pm 1.494$ \\
\hline $\mathrm{Pb} 150+\mathrm{Cur}$ & 16.531 & 17.755 & 14.898 & 14.286 & 11.837 & 12.245 & $14.592 \pm 2.326$ \\
\hline
\end{tabular}

\subsection{Determination of Lead Concentration in Liver}

Elevated level of lead was determined in liver samples of mice treated with lead solution, and administration of curcumin seemed to reduce it (Table 2). There are several studies that have reported that higher level of lead in organs. Amriani et al., (2011) observed that there was an increase in lead and zinc levels in shells of Anadara granosa and Polymesoda bengalensis from heavy metals-contaminated Kendari Bay. Faix et al., (2005) observed that the concentration of lead was significantly higher in the rumen, colon, liver and kidneys in the sheep that have been long-term high heavy metal intake. The impact of lead pollution was also observed in vegetables (Fauziah et al., 2011; Ugya and Imam, 2017).

Table 2. Concentration of lead in the liver $(\mathrm{mg} / \mathrm{kg})$

\begin{tabular}{|c|c|c|c|}
\hline \multirow{2}{*}{ Treatments } & \multicolumn{2}{|c|}{ Replication } & \multirow[t]{2}{*}{ Conc. of Lead \pm SD $(\mathrm{mg} / \mathrm{kg})$} \\
\hline & 1 & 2 & \\
\hline Control & 0.023 & 0.028 & $0.026 \pm 0.004$ \\
\hline $\mathrm{Pb} 75$ & 0.073 & 0.068 & $0.071 \pm 0.004$ \\
\hline $\mathrm{Pb} 150$ & 0.075 & 0.064 & $0.070 \pm 0.008$ \\
\hline $\mathrm{Pb} 75+\mathrm{Cur}$ & 0.032 & 0.037 & $0.035 \pm 0.004$ \\
\hline $\mathrm{Pb} 150+\mathrm{Cur}$ & 0.036 & 0.040 & $0.038 \pm 0.003$ \\
\hline
\end{tabular}



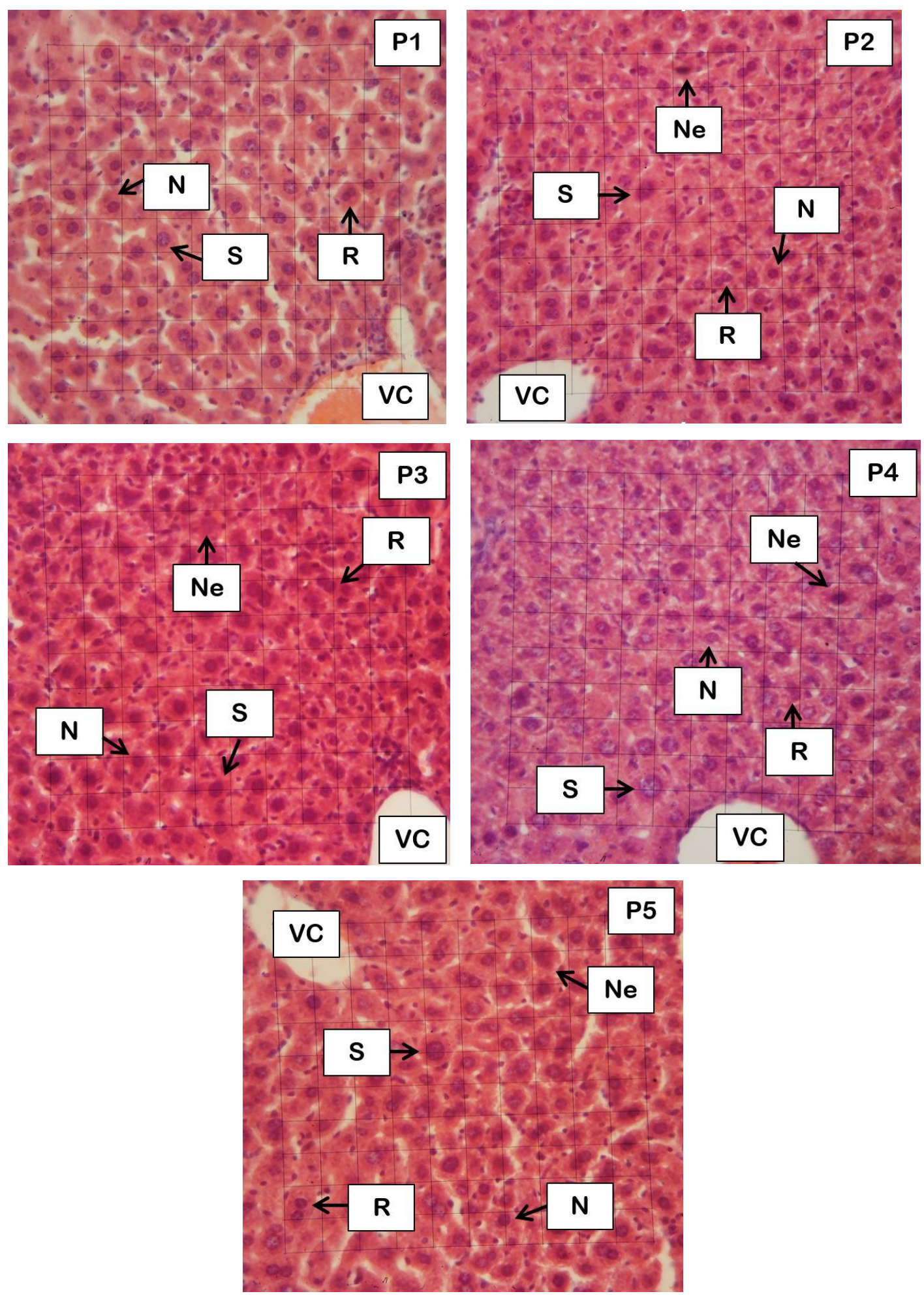

Figure 2. Hepatocyte cells, $\mathrm{N}=$ normal; $\mathrm{S}=$ swollen; $\mathrm{R}=$ regeneration; $\mathrm{Ne}=$ necrosis; $\mathrm{VC}=$ vena centralis. $\mathrm{P} 1=$ Control; $\mathrm{P} 2=\mathrm{Pb} 75 ; \mathrm{P} 3=\mathrm{Pb} 150 ; \mathrm{P} 4=\mathrm{Pb} 75+\mathrm{Cur} ; \mathrm{P} 5=\mathrm{Pb} 150+\mathrm{Cur}$ (Magnification $400 \times$ ) 
Table 3. The histopathology of hepatocyte cells

\begin{tabular}{lcccc}
\hline \multirow{2}{*}{ Treatment } & \multicolumn{4}{c}{ \% Hepatocyte cells } \\
\cline { 2 - 5 } & Normal & Necrosis & Swollen & Regeneration \\
\hline Control & $70.96 \pm 5.40^{\mathrm{a}}$ & $9.33 \pm 4.51^{\mathrm{a}}$ & $7.59 \pm 2.00^{\mathrm{a}}$ & $12.11 \pm 2.06^{\mathrm{a}}$ \\
$\mathrm{Pb} \mathrm{75}$ & $37.01 \pm 3.09^{\mathrm{c}}$ & $29.99 \pm 4.90^{\mathrm{c}}$ & $17.36 \pm 1.02^{\mathrm{cd}}$ & $15.63 \pm 5.41^{\mathrm{a}}$ \\
$\mathrm{Pb} \mathrm{150}$ & $41.40 \pm 4.22^{\mathrm{c}}$ & $27.33 \pm 7.32^{\mathrm{c}}$ & $16.11 \pm 6.86^{\mathrm{bc}}$ & $13.00 \pm 1.00^{\mathrm{a}}$ \\
$\mathrm{Pb} \mathrm{75+Cur}$ & $36.85 \pm 1.53^{\mathrm{c}}$ & $30.24 \pm 1.42^{\mathrm{c}}$ & $21.54 \pm 1.90^{\mathrm{d}}$ & $11.37 \pm 1.73^{\mathrm{a}}$ \\
$\mathrm{Pb} \mathrm{150+Cur}$ & $52.08 \pm 5.95^{\mathrm{b}}$ & $20.76 \pm 2.58^{\mathrm{b}}$ & $12.54 \pm 1.42^{\mathrm{b}}$ & $14.62 \pm 2.94^{\mathrm{a}}$ \\
\hline
\end{tabular}

The different letters show significant differences in the Duncan's test $(p<0.05)$

Liver histopathology showed that lead exposure increased the number of necrotic cells and the swollen cells, concomitantly decreasing the normal cells (Figure 2, Table 3). Lead may induce oxidative stress and change the expressions of apoptosis-related proteins in mouse liver (Xu et al., 2008). Hayati et al., (2017) observed that heavy metals in the liver of Barbodes sp. can cause cell damage and necrosis cells. Exposure to lead and aluminum may increase the risk of congenital heart disease (CHD) occurrence, and may lead to a decline in the activity of antioxidant enzymes (Liu et al., 2018).

Sugiharto et al., (2018) observed that curcumin as an antioxidant can restore the damaged cells. The potential protective effects of curcumin mainly attributed to its antioxidant properties against heavy metals intoxication. Curcumin has strong antioxidant property by acting as ROS scavengers, hydrogen donors, increasing the SOD activity, reducing MDA levels (Molyneux, 2004; Shah and Jain, 2016). The 1,3-diketone moiety of curcumin can readily chelate heavy metal ions (Raj and Shankaran, 2016). It's also relate to high tendency of chelating heavy metals. Curcumin prevents structural damage and increases antioxidant enzymes to protecting hepatic cells from oxidative damage (Khan et al., 2019).

\section{CONCLUSION}

Curcumin exhibited strong antioxidant activity with IC50 $9.0 \mathrm{ppm}$. Lead exposure increased MDA and $\mathrm{Pb}$ levels in the liver. Administration of curcumin at 20 ppm have the potential to reduced MDA level and $\mathrm{Pb}$ level $/ \mathrm{kg} \mathrm{BW}$.

\section{ACKNOWLEDGMENTS}

We would like to thank to Faculty Sciences and Technology, Universitas Airlangga, for research grant No.1915/UN3.1.8/LT/2018.

\section{REFERENCES}

Al-Fartosy A.J.M., Shanan S.K., and Awad N.A., (2017). Biochemical Study of The Effects of Some Heavy Metals on Oxidant Antioxidant Status in Gasoline Station Workers BasraIraq, International Journal of Scientific and Research Publications, 7(2): 83-94.

Amriani, Hendrarto B., and Hadiyarto A., (2011). Bioakumulasi Logam Berat 
Timbal (Pb) Dan Seng (Zn) Pada Kerang Darah (Anadara granosa L.) Dan Kerang Bakau (Polymesoda bengalensis L.) Di Perairan Teluk Kendari, Jurnal Ilmu Lingkungan 9(2): 45-50.

Faix S., Z. Faixova Z., Boldizarova K., and Javorsky P., (2005). The Effect of Long-Term High Heavy Metal Intake on Lipid Peroxidation of Gastrointestinal Tissue in Sheep, Veterinárni Medicina - Czech 50(9): 401-405.

Fauziah S.H., NurHajar W.S., and Agamuthu P., (2011). Heavy Metal Accumulation in Ipomoea reptans and Helianthus annuus, Malaysian Journal of Science 30(1): 36-44.

Flora G., Gupta D., and Tiwari A., (2012). Toxicity of Lead: A Review With Recent Updates, Interdisciplinary Toxicology 5(2): 47-58.

Fuente H.D., Perez D.P., Baranda L., Barriga F.D., Alanis V.S, Layseca E., and Amaro R.G., (2002). Effect of Arsenic, Cadmium, and Lead on The Induction Apoptosis of Normal Human Mononuclear Cells, Clinical \& Experimental Immunology 129: 69-77.

Hayati A., Sugiharto, Abdizen M., Solikha B.M., Maulidyah N., Tiantono N., Seta A.R., Widyana H., Restinastiti I., Ziky D., and Winarni D., (2017). Bioaccumulation of Heavy Metals in Fish (Barbodes sp.) Tissues in the Brantas River, Indonesia, Journal of Applied Environmental and Biological Sciences 7(3): 139-143.

Khan H., Ullah H., and Nabavi S.M., (2019). Mechanistic Insights of Hepatoprotective Effects of Curcumin: Therapeutic Updates and Future Prospects, Food and Chemical Toxicology 124: 182-191.
Lee K., Aziz F.H., Syahida A., Abas F., Shaari K., Israf D.A., and Lajis N.H., (2009). Synthesis and Biological Evaluation of Curcumin-Like Diarylpentanoid Analogues for AntiInflammatory, Antioxidant and AntiTyrosinase Activities, European Journal of Medicinal Chemistry 44(8): 3195-3200.

Liu Z., He C., Chen M., Yang S., Li J., Lin Y., Deng Y., Li N., Guo Y., Yu P., and Li X., (2018). The Effects of Lead and Aluminum Exposure on Congenital Heart Disease and The Mechanism of Oxidative Stress, Reproductive Toxicology 81: 93-98. Molyneux P., (2004). The Use of The Stable Free Radical Diphenylpicrylhydrazyl (DPPH) for Estimating Antioxidant Activity, Songklanakarin Journal of Sciences and Technology 26(2): 211-219.

Nimse S.B., and Pal D., (2015). Free Radicals, Natural Antioxidants, and Their Reaction Mechanisms, RSC Advances 5: 27986-28006.

Priyadarsini K. I., Maity D. K., Naik G. H., Kumar M. S., Unnikrishnan M. K., Satav J. G., and Mohan H. (2003). Role of Phenolic O-H and Methylene Hydrogen on the Free Radical Reactions and Antioxidant Activity of Curcumin, Free Radical Biology and Medicine, 35(5): 475-484.

Raj S., and Shankaran D.R., (2016). Curcumin Based Biocompatible Nano-fibers For Lead Ion Detection, Sensors and Actuators B 226: 318325.

Shah F.C., and Jain N.K., (2016). Ameliorative Action of Synthetic and Herbal Antioxidants on Lead Induced Hepatotoxicity: An In Vitro Study, Asian Journal of 
Pharmaceutical and Clinical Research 9(2) : 364-370.

Sharma S., and Singh B., (2014). Effects of Acute and Chronic Lead Exposure on Kidney Lipid Peroxidation and Antioxidant Enzyme Activities in BALB-C Mice (Mus musculus), International Journal of Science and Research 3(9): 1564-1566.

Sugiharto, Arbakariya A., Syahida A., and Muhajir H., (2013). Properties of Curcumin: Assay of Tyrosinase Activities, Proceeding of 4th ICOWOBAS-RAFSS, UTMMalaysia, 80-82.

Sugiharto, Arbakariya A., Syahida A., and Muhajir H., (2016). Properties of Kojic Acid and Curcumin: Assay on Cell B16-F1, 5th ICOWOBAS 2015, AIP Conference Proceedings 1718,
060006;

https://doi.org/10.1063/1.4943328

Sugiharto, Win Darmanto, and Sri Puji A.W., (2018). Antioxidant Activity of Curcumin on Blood Serum Assay and Liver Cells of Mice, Research Report, Faculty of Sciences and Technology, Airlangga University.

Ugya A.Y., and Imam T.S., (2017). Temporal Heavy Metal Variation in Vegetables Sampled at Kasuwan Mata, Kaduna Metropolis, Nigeria, Malaysian Journal of Science 36(2): 63-74.

Xu J., Lian L.J., Wu C., Wang X.F., Fu W.Y., and Xu L. H., (2008). Lead Induces Oxidative Stress, DNA Damage and Alteration of p53, Bax and Bcl-2 Expressions in Mice, Food and Chemical Toxicology 46(5): 1488-1494. 